\title{
Legitimacy under institutional complexity: Mapping stakeholder perceptions of legitimate institutions and their sources of legitimacy in global renewable energy governance
}

\author{
Naghmeh Nasiritousi ${ }^{1 \star}$ (D) and Hugo Faber ${ }^{2}$ (D) \\ ${ }^{1}$ Department of Political Science, Stockholm University, Stockholm, Sweden and ${ }^{2}$ School of Social Sciences, Södertörn \\ University, Huddinge, Sweden \\ *Corresponding author. Email: naghmeh.nasiritousi@statsvet.su.se
}

(Received 20 January 2020; revised 11 November 2020; accepted 11 November 2020;

first published online 14 December 2020)

\begin{abstract}
The legitimacy of international institutions has in recent years received growing interest from scholars, yet analyses of stakeholder perceptions of the legitimacy of institutions that coexist within a governance field have been few in number. Motivated by the proliferation of institutions in the field of global climate and energy governance, this study maps stakeholder perceptions of legitimate institutions and their sources of legitimacy in global renewable energy governance. Specifically, the article makes three contributions to the existing literature. Theoretically, it unpacks the legitimacy concept and offers a multidimensional conception of legitimacy. Methodologically, it captures these different dimensions of legitimacy by relying on three open survey questions. Empirically, it maps legitimacy perceptions among climate and energy experts and not only shows which institutions are considered most legitimate, but also why they are considered legitimate and how this varies between different stakeholders. The article thereby contributes to the literature on legitimacy by providing new insights into the sources of legitimacy among international institutions that operate under institutional complexity.
\end{abstract}

Keywords: Legitimacy; Global Renewable Energy Governance; Institutional Complexity; International Institutions

\section{Introduction}

Global governance is today made up of a patchwork of international institutions that operate with different, albeit sometimes overlapping mandates. The International Relations literature has shown that international institutions matter and that they can make a positive contribution to solving international problems. ${ }^{1}$ Recent studies have highlighted the importance of institutions being considered legitimate in order to be stable and function effectively. ${ }^{2}$ It is therefore important to understand both the extent to which different international institutions are considered legitimate, and the sources of legitimacy in terms of the institutional traits that leads to an

\footnotetext{
${ }^{1}$ Oran R. Young, 'Effectiveness of international environmental regimes: Existing knowledge, cutting-edge themes, and research strategies', PNAS, 108:50 (2011), pp. 19853-860; Edward L. Miles et al., Environmental Regime Effectiveness: Confronting Theory with Evidence (Cambridge, MA: The MIT Press, 2002).

${ }^{2}$ Steinar Andresen and Ellen Hey, 'The effectiveness and legitimacy of international environmental institutions', International Environmental Agreements: Politics, Law and Economics, 5:3 (2005), pp. 211-26; Jonas Tallberg and Michael Zürn, 'The legitimacy and legitimation of international organizations: Introduction and framework', Review of International Organizations, 14 (2019), pp. 581-606.

(C) The Author(s), 2020. Published by Cambridge University Press on behalf of the British International Studies Association. This is an Open Access article, distributed under the terms of the Creative Commons Attribution licence (http://creativecommons.org/licenses/by/4.0/), which permits unrestricted re-use, distribution, and reproduction in any medium, provided the original work is properly cited.
} 
institution being considered legitimate. These questions are of particular interest in an era where the fragmentation of global governance institutions means that there is competition between institutions over members and resources. ${ }^{3}$ What this means for issues of legitimacy of global governance institutions remains a pertinent question.

The aim of this article is to examine perceptions of legitimacy in an institutionally complex field, namely the global renewable energy field. This field is interesting to examine for a number of reasons. First, according to Dries Lesage et al. 'without any doubt, energy is to become one of the major international political issues of the 21 st century. ${ }^{4}$ This is not least because it is widely agreed that addressing climate change requires the transformation of energy systems. ${ }^{5}$ Since the Sustainable Development Goal (SDG) \#7 is to 'Ensure access to affordable, reliable, sustainable and modern energy for all', ${ }^{6}$ the need for international cooperation has increased to remove barriers for joint projects and encourage international policy coordination. The effectiveness and legitimacy of institutions in this field are thus of great importance for the achievement of this goal. $^{7}$ Second, in the last two decades, there has been a proliferation of institutions and initiatives that focus attention on renewable energy. These include multilateral ones and minilateral ones, public, private, and hybrid ones. ${ }^{8}$ Given the possibilities of forum shopping, an examination of perceptions of legitimacy of stakeholders of global renewable energy governance can provide insights into how policymakers and other stakeholders decide on which institutions to engage in.

From an academic point of view, the global renewable energy field can be seen as a case of a wider trend in global governance whereby authority in a given issue-area is increasingly shared between a set of institutions with varying memberships. ${ }^{9}$ With a proliferation of institutions within a given governance field, the operations of individual institutions become more interdependent, which may have implications for their legitimacy. ${ }^{10}$ While this article does not focus on how institutional complexity affects legitimacy, it does seek to understand the legitimacy perceptions of stakeholders in an institutionally complex governance field. The field is characterised by multiple institutions working at different levels involving a range of different sectors, actors, and interests. ${ }^{11}$ While there exists no intense, direct competition between the multitude of institutions in the renewable energy field, the fact that they have overlapping mandates means that stakeholders have alternatives when assessing and engaging with these institutions. An

\footnotetext{
${ }^{3}$ Andresen and Hey, 'The effectiveness and legitimacy of international environmental institutions'; Sylvia I. Karlsson-Vinkhuyzen and Jeffrey McGee, 'Legitimacy in an era of fragmentation: The case of global climate governance', Global Environmental Politics, 13:3 (2013), pp. 56-78.

${ }^{4}$ Dries Lesage et al., Global Energy Governance in a Multipolar World (New York: Routledge 2016), p. 2.

${ }^{5}$ Fariborz Zelli et al., 'Global climate governance and energy choices', in Andreas Goldthau (ed.), The Handbook of Global Energy Policy (Chichester: John Wiley \& Sons Ltd, 2013); Navroz K. Dubash, 'Climate change through the lens of energy transformation', in Simon Nicholson and Sikina Jinnah (eds), New Earth Politics: Essays from the Anthropocene (Cambridge, MA: MIT Press, 2016), pp. 315-42.

${ }^{6}$ United Nations, 'Ensure Access to Affordable, Reliable, Sustainable and Modern Energy', available at: \{http://www.un.org/ sustainabledevelopment/energy/\}.

${ }^{7}$ Sylvia I. Karlsson-Vinkhuyzen, 'The legitimation of global energy governance: A normative exploration', in François Mancebo and Ignacy Sachs (eds), Transitions to Sustainability (Dordrecht: Springer, 2015), pp. 119-30.

${ }^{8}$ Zelli et al., 'Global climate governance and energy choices'; Thijs Van de Graaf, The Politics and Institutions of Global Energy Governance (Hampshire and New York: Palgrave Macmillan, 2013); Lisa Sanderink et al., 'Mapping the institutional complex of the climate-energy nexus', in Zelli et al. (eds), Governing the Climate-Energy Nexus: Institutional Complexity and its Challenges to Effectiveness and Legitimacy (Cambridge: Cambridge University Press, 2020), pp. 43-98.

${ }^{9}$ See also Benjamin Faude and Kenneth W. Abbott, 'Choosing low-cost institutions in global governance', International Theory, Online First (2020), ISSN 1752-9719.

${ }^{10}$ Benjamin Faude and Felix Große-Kreul, 'Let's justify! How regime complexes enhance the normative legitimacy of global governance', International Studies Quarterly, 64:2 (2020), pp. 431-9.

${ }^{11}$ Ann Florini and Benjamin K. Sovacool, 'Bridging the gaps in global energy governance', Global Governance: A Review of Multilateralism and International Organizations, 17:1 (2011), pp. 57-74; Goldthau (ed.), The Handbook of Global Energy Policy; Thijs Van de Graaf and Jeff Colgan, 'Global energy governance: A review and research agenda', Palgrave Communications, 2:1 (2020).
} 
investigation into which institutions are perceived to be highly legitimate in this field, and the reasons for being perceived so, is thus important both from an academic and a policy perspective.

The article builds on literature that depicts legitimacy as a multidimensional concept and which highlights that perceptions of legitimacy depend on both moral and instrumental considerations. ${ }^{12}$ Indeed, different stakeholders may consider the same institution legitimate, but for completely different reasons. ${ }^{13}$ Thus, the importance and variability of legitimacy generates two questions of interest for political scientists and policymakers: (1) Which institutions working within the same issue-area are considered most legitimate and why?; and (2) How do these perceptions of legitimacy vary across different stakeholder groups?

In order to answer these questions for the issue-area of renewable energy, this article employs unique questionnaire data that gauges the views of climate and energy experts. In contrast to much of the previous literature, the survey captures the concept of legitimacy through open questions, providing the respondents the chance to themselves identify what makes an institution legitimate. The results show surprising agreement among groups of stakeholders on the most legitimate institutions promoting renewable energy globally. The reasons for viewing those institutions as legitimate, however, varies - and depends on how the question is posed. The article thereby contributes to the literature on legitimacy by providing new insights into the sources of legitimacy among international institutions that operate under institutional complexity.

Specifically, the article contributes to three broad debates on the legitimacy of institutions found in the International Relations literature. First, the article contributes to the debate in the literature on which institutional qualities that generate legitimacy for an institution as perceived by stakeholders. ${ }^{14}$ Here we offer new empirical and methodological perspectives on this issue. Second, the study contributes to the literature on the legitimacy on the old and new forms of governance. ${ }^{15}$ With the establishment of institutions that have non-state actors as members and new governance arrangements, it is interesting to examine whether they enjoy the same extent of legitimacy as more traditional international institutions. Finally, the article provides new conceptual discussions into how legitimacy can be understood by stakeholders and how it can be operationalised in empirical research. ${ }^{16}$

The article proceeds as follows. The next section discusses the concept of legitimacy and different sources of legitimacy that have been highlighted in previous literature. Thereafter, the crowded institutional landscape of renewable energy governance is outlined, and expectations drawn up for how this may affect the legitimacy of individual institutions. Next, data and methods are described before the results are presented. The final section concludes by drawing out implications for legitimacy in global renewable energy governance.

\footnotetext{
${ }^{12}$ Lisa Dellmuth and Bernd Schlipphak, 'Legitimacy beliefs towards global governance institutions: A research agenda', Journal of European Public Policy, 27:6 (2019), pp. 931-43.

${ }^{13}$ Dane Imerman, 'Contested legitimacy and institutional change: Unpacking the dynamics of institutional legitimacy', International Studies Review, 20:1 (2018), pp. 74-100.

${ }^{14}$ Marin Binder and Monika Heupel, 'The legitimacy of the UN Security Council: Evidence from recent General Assembly debates', International Studies Quarterly, 59:2 (2015), pp. 238-50; Thomas Bernauer et al., 'Do citizens evaluate international cooperation based on information about procedural and outcome quality?', Review of International Organizations, 15 (2019), pp. 505-29; Lisa Dellmuth et al., 'Institutional sources of legitimacy for international organisations: Beyond procedure versus performance', Review of International Studies, 45:4 (2019), pp. 627-46; Tallberg and Zürn, 'The legitimacy and legitimation of international organizations'.

${ }^{15}$ Steven Bernstein, 'Legitimacy in intergovernmental and non-state global governance', Review of International Political Economy, 18:1 (2011), pp. 17-51; Jonas Tallberg, 'The legitimacy of old and new modes of global governance', in Michael Barnett et al. (eds), The Evolution of Global Governance: Hierarchies, Markets, and Networks (Cambridge: Cambridge University Press 2020).

${ }^{16}$ Hans Agné et al., 'Does stakeholder involvement foster democratic legitimacy in international organizations? An empirical assessment of a normative theory', Review of International Organizations, 10:4 (2015), pp. 465-88; Jennifer Gronau and Henning Schmidtke, 'The quest for legitimacy in world politics: International institutions' legitimation strategies', Review of International Studies, 42:3 (2016), pp. 535-57; Dellmuth and Schlipphak, 'Legitimacy beliefs towards global governance institutions'.
} 


\section{Unpacking legitimacy}

The concept of legitimacy has been discussed extensively in previous literature. ${ }^{17}$ Broadly legitimacy refers to 'the acceptance and justification of shared rule by a community. ${ }^{18}$ While traditionally legitimacy was considered an attribute of states, more recently legitimacy has been argued to be important also for international institutions and other actors operating on the global scene. For instance, there has been a range of studies on the legitimacy of governance institutions beyond the nation-state, such as regional organisations or multi-stakeholder initiatives. ${ }^{19}$ Legitimacy is a central concept for governance scholars, since legitimacy can generate compliance with shared rules without the need for inducement or coercion. ${ }^{20}$

In essence, legitimate institutions are those that have obtained acceptability and credibility in the eyes of the community that it seeks to govern. Legitimacy is thus a dual concept. It can both refer to what ought to be viewed as legitimate based on common norms and standards, and what is in fact viewed as legitimate by a range of stakeholders. ${ }^{21}$ The former is associated with the normative approach to legitimacy while the latter is associated with sociological legitimacy. In contrast to the normative approach, a sociological approach focuses on legitimacy as it is perceived by key stakeholders rather than according to predefined normative standards, and opens up for an assessment of how an institution performs in terms of legitimacy in practice rather than in principle. ${ }^{22}$ According to Allen Buchanan and Robert Keohane, 'It is important not only that global governance institutions be legitimate, but that they are perceived to be legitimate., ${ }^{23}$

How, then, can institutions strive to gain this acceptability and credibility? In the words of Daniel Bodansky, ${ }^{24}$ there are three main types of legitimacy - 'source-based, procedural, and substantive'. Source-based legitimacy stems from the internal properties of the institution, for example its identity and purpose. ${ }^{25}$ Procedural legitimacy stems from the decision-making processes of an institution, including criteria such as transparency, accountability, inclusion of all appropriate actors, impartiality, and procedural fairness. In other words, this is a combination of 'input ${ }^{26}$ and 'throughput' ${ }^{27}$ legitimacy, that is, referring to the internal governance processes of an institution. Substantive legitimacy, on the other hand, stems from what is produced by an institution and the effect that this has in terms of behavioural change, problem solving, and the

\footnotetext{
${ }^{17}$ Mark C. Suchman, 'Managing legitimacy: Strategic and institutional approaches', The Academy of Management Review, 20:3 (1995), pp. 571-610; Ian Hurd, 'Legitimacy and authority in international politics', International Organization, 53:2 (1999), pp. 379-408; Steven Bernstein, 'Legitimacy in global environmental governance', Journal of International Law and International Relations, 1 (2005), pp. 139-66; Allen Buchanan and Robert O. Keohane, 'The legitimacy of global governance institutions', Ethics and International Affairs, 20:4 (2006), pp. 405-37; Robert O. Keohane, 'Global governance and legitimacy', Review of International Political Economy, 18:1 (2011), pp. 99-109.

${ }^{18}$ Bernstein, 'Legitimacy in global environmental governance', p. 142.

${ }^{19}$ Andrew Moravcsik, 'Reassessing legitimacy in the European Union', Journal of Common Market Studies, 40 (2002), pp. 603-24; Thomas Banchoff and Mitchell P. Smith, Legitimacy in the European Union: The Contested Polity (London: Routledge, 2005); Steven Bernstein and Benjamin Cashore, 'Can non-state global governance be legitimate? An analytical framework', Regulation \& Governance, 1 (2007), pp. 347-71; Agné et al., 'Does stakeholder involvement foster democratic legitimacy in international organizations?'; Brilé Anderson et al., 'Does international pooling of authority affect the perceived legitimacy of global governance?', Review of International Organizations, 14:4 (2019), pp. 661-83.

${ }^{20}$ Bernstein, 'Legitimacy in intergovernmental and non-state global governance'.

${ }^{21}$ Buchanan and Keohane, 'The legitimacy of global governance institutions'.

${ }^{22}$ Jonas Tallberg et al. (eds), Legitimacy in Global Governance: Sources, Processes, and Consequences (Oxford: Oxford University Press 2018), p. 5.

${ }^{23}$ Keohane, 'The legitimacy of global governance institutions', p. 407.

${ }^{24}$ Daniel Bodansky, 'The legitimacy of international governance: A coming challenge for international environmental law?', American Journal of International Law, 93:3 (1999), p. 612.

${ }^{25}$ Karlsson-Vinkuyzen and McGee, 'Legitimacy in an era of fragmentation'.

${ }^{26}$ Fritz w. Scharpf, Governing in Europe: Effective and Democratic? (Oxford: Oxford University Press, 1999).

${ }^{27}$ Vivien A. Schmidt, 'Democracy and legitimacy in the European Union revisited: Output, input and "throughput", Political Studies, 61 (2010), pp. 2-22.
} 
fair distribution of benefits. ${ }^{28}$ Another common term for substantive legitimacy is thus 'output' legitimacy, ${ }^{29}$ referring to the effects of the decisions made by the institution. Following Tobias Lenz and Lora Anne Viola, ${ }^{30}$ we simplify these three dimensions to the three Ps - purpose, procedure, and performance. Thus, we use the term 'purpose' for the institutional properties associated with the source-based dimension, 'procedure' for the properties associated with input and throughput, and 'performance' for the properties associated with output legitimacy. ${ }^{31}$ These three broad categories of sources of legitimacy thus encompass the institution's aim and its internal properties to fulfill this aim (purpose), the internal processes of the institution (procedure), and what it produces (performance).

Interestingly, the scholarly debate on the sources of institutional legitimacy has focused mostly on the procedure and performance of institutions. Discussions have concerned whether procedure or performance matters more for an institutions' legitimacy ${ }^{32}$ and whether there are synergies or trade-offs between procedure or performance. ${ }^{33}$ Purpose has typically been discussed in the literature as the social purpose of an institution, including a legitimate goal and rationale. ${ }^{34}$ We take a broader view of purpose and also include an institution's mandate and its basic setup so that purpose includes not only goals and rationale, but also the identity and internal properties of an institution. A reason for why purpose has not been examined to a great extent may be that procedure and performance matter more when comparing the legitimacy of institutions across different fields. In an institutional regime complex, however, many institutions have overlapping functions and therefore we posit that purpose may matter more to perceptions of legitimacy. In other words, when there are more than one institution working in the same field, perceptions of legitimacy may be shaped by the existence of alternative governance arrangements with slightly different purposes. ${ }^{35}$

Although there has been a growing scholarly interest in the sociological approach to legitimacy in international institutions, empirical studies on the subject are still few in number. Most studies use confidence or support as a proxy for legitimacy ${ }^{36}$ and use questionnaires to seek to quantify it. The advantage of this approach is that it measures the extent to which a community finds an

\footnotetext{
${ }^{28}$ Fariborz Zelli et al., 'Analytical framework: Assessing coherence, management, legitimacy, and effectiveness', in Zelli et al. (eds), Governing the Climate-Energy Nexus, pp. 21-42.

${ }^{29}$ Scharpf, Governing in Europe.

${ }^{30}$ Tobias Lenz and Lora Anne Viola, 'Legitimacy and institutional change in international organisations: a cognitive approach', Review of International Studies, 43 (2017), pp. 939-61.

${ }^{31}$ Jan Aart Scholte and Jonas Tallberg, 'Theorizing the institutional sources of global governance legitimacy', in Tallberg et al. (eds), Legitimacy in Global Governance, pp. 56-74.

${ }^{32}$ Lisa Dellmuth and Jonas Tallberg, 'The social legitimacy of international organizations: Interest representation, institutional performance, and confidence extrapolation in the United Nations', Review of International Studies, 41:3 (2015), pp. 451-75; Bernauer et al., 'Do citizens evaluate international cooperation'; Dellmuth et al., 'Institutional sources of legitimacy for international organisations'.

${ }^{33}$ Scharpf, Governing in Europe; Thomas Risse, 'Global governance and communicative action', Government and Opposition, 39 (2004), pp. 288-313; Arthur Benz, 'Accountable multilevel governance by the open method of coordination?', European Law Journal, 13 (2007), pp. 505-22; Marianne Beisheim and Klaus Dingwerth, 'Procedural Legitimacy and Private Transnational Governance: Are the Good Ones Doing Better?', Sfb-Governance Working Paper Series, 14 (2008); Karl-Oskar Lindgren and Thomas Persson, 'Input and output legitimacy: Synergy or trade-off? Empirical evidence from an EU survey', Journal of European Public Policy, 17:4 (2010), pp. 449-67; Karl Hogl et al., Environmental Governance: The Challenge of Legitimacy and Effectiveness (Cheltenham: Edward Elgar, 2012).

${ }^{34}$ John Gerard Ruggie, Constructing the World Polity: Essays on International Institutionalization (New York: Routledge, 1998); Bernstein, 'Legitimacy in intergovernmental and non-state global governance'.

${ }^{35}$ See Bäckstrand et al., 'The legitimacy and accountability in polycentric climate governance', in Andrew Jordan et al. (eds), Governing Climate Change Polycentricity in Action? (Cambridge: Cambridge University Press, 2020), pp. 338-56; Naghmeh Nasiritousi and Soetkin Verhaegen, 'Disentangling legitimacy: Comparing stakeholder assessments of five key climate and energy governance institutions', in Zelli et al. (eds), Governing the Climate-Energy Nexus, pp. 183-211.

${ }^{36}$ James L. Gibson and Gregory A. Caldeira, 'Changes in the legitimacy of the European Court of Justice: A post-Maastricht analysis', British Journal of Political Science, 28:1 (1998), pp. 63-91; Dellmuth and Tallberg, 'The social legitimacy of international organizations'.
} 
institution credible and worthy of backing. The disadvantage, however, is that it may not capture different dimensions of legitimacy and that it does not examine the sources of this legitimacy. Moreover, by presenting a list of institutions and asking respondents to express their level of confidence in those institutions, closed questions measure latent, or even created perceptions of legitimacy as respondents may not have formed opinions about the presented institutions.

This study therefore adopts a different approach. It seeks to better understand how stakeholders perceive the legitimacy of institutions within global renewable energy governance to understand which institutions are considered most legitimate and why. The sociological approach is thus applied, since we are interested in understanding stakeholder perceptions. Rather than asking respondents about specific institutions, respondents are asked a set of open questions about different aspects of legitimacy to see how purpose, procedure, and performance of institutions shape perceptions of legitimacy. To the best of our knowledge, this approach has not been employed in previous legitimacy studies, and thus this study is aimed at making theoretical contributions rather than engaging in theory testing. In what follows we describe the institutional complex of global renewable energy governance and outline a set of general expectations of how perceptions of legitimacy may be affected by the purpose, procedure, and performance of institutions.

\section{The institutional complex of global renewable energy governance}

Global renewable energy governance lies at the intersection of global climate and energy governance, two fields of governance that are often described as 'fragmented', complex, and polycentric. ${ }^{37}$ Both policy fields can be characterised by 'increasing systemic interdependencies, externalities spilling beyond national borders and a decreasing regulatory capacity of individual states'. ${ }^{38}$ While international cooperation is important to address these issues, states have been wary of giving up sovereignty to create strong international institutions in these fields. ${ }^{39}$ This has resulted in a patchwork of institutions with overlapping mandates, involving different actors and levels, and both direct and indirect forms of governance. ${ }^{40}$ To understand global renewable energy governance, it is important to note that renewable energy is a critical component in mitigating climate change, but it is also a means of expanding energy access, diversifying energy supply, and to alleviate environmental problems such as air and water pollution. Institutions in global renewable energy governance may thus emphasise different aspects of renewable energy and promote it for different reasons, which may result in tensions and even conflicts. ${ }^{41}$ There are also several different renewable energy sources, and accordingly there are institutions that promote each of the specific sources as well as institutions that promote renewable energy in general.

\footnotetext{
${ }^{37}$ Aleh Cherp et al., 'Governing global energy: Systems, transitions, complexity', Global Policy, 2:1 (2011), pp. 75-88; Kenneth W Abbott, 'The transnational regime complex for climate change', Environment and Planning C: Government and Policy, 30 (2012), pp. 571-90; Van de Graaf, The Politics and Institutions of Global Energy Governance; Andreas Goldthau, 'Rethinking the governance of energy infrastructure: Scale, decentralization and polycentrism', Energy Research \& Social Science, 1 (2014), pp. 134-40; Gonzalo Escribano, 'Fragmented energy governance and the provision of global public goods', Global Policy, 6:2 (2015), pp. 97-106; Mattias Hjerpe and Naghmeh Nasiritousi, 'Views on alternative forums for effectively tackling climate change', Nature Climate Change, 5:9 (2015), pp. 864-67.

${ }^{38}$ Cherp et al., 'Governing global energy', p. 76.

${ }^{39}$ Jeffrey D. Wilson, 'Multilateral organisations and the limits to international energy cooperation', New Political Economy, 20:1 (2015), pp. 85-106; Naghmeh Nasiritousi and Karin Bäckstrand, 'International climate policy in the post-Paris era', in Lars Calmfors and John Hassler (eds), Nordic Economic Policy Review: Climate Policies in the Nordics (Copenhagen: Nordic Council of Ministers, 2019), pp. 21-50.

${ }^{40}$ Christian Downie, 'Steering global energy governance: Who governs and what do they do?', Regulation \& Governance (2020), available at: \{doi: https://doi.org/10.1111/rego.12352\}.

${ }^{41}$ Sybille Roehrkasten, 'Global governance on renewable energy', in Sybille Roehrkasten, Global Governance on Renewable Energy: Contrasting the Ideas of the German and the Brazilian Governments (Wiesbaden: Springer Fachmedien Wiesbaden, 2015), pp. 73-116; Lisa Sanderink, 'Renewable energy: A loosely coupled system or a well-connected web of institutions?', in Zelli et al. (eds), Governing the Climate-Energy Nexus, pp. 101-30.
} 
Global renewable energy governance has seen a significant rise in the numbers of institutions in the last few decades. Except for the International Solar Energy Society that was established already in 1954, the oldest institutions in global renewable energy governance date back to the 1970 s and were initiated as a way of managing rising energy security concerns after the OPEC oil crises. The number of institutions in global renewable energy governance began to grow in the 1990s, primarily due to the growing salience of the climate change issue, manifested in the adoption of the United Nations Framework Convention on Climate Change (UNFCCC) and the Kyoto Protocol. ${ }^{42}$ A recent mapping of global renewable energy institutions found a total of 46 institutions, of which 19 focus specifically on renewable energy. ${ }^{43}$ Thus, today renewable energy governance is populated by a large number of institutions with varying forms and functions, and without a clear division of labour. ${ }^{44}$

Most institutions in global renewable energy governance draw their members from public actors, but there are organisations made up of civil society actors and corporate actors as well. There are also several multi-stakeholder partnerships, with members representing all these types of actors. ${ }^{45}$ These institutions fulfill different functions, with information exchange and networking being the most common, followed by operational activities such as capacity building, and less often developing standards and financing. Global renewable energy governance has thus been fittingly described as 'institutionally complex'. ${ }^{46}$

A number of institutions are worth presenting in a little more detail, as they occupy a central place in the field of global renewable energy governance. ${ }^{47}$ They and some of their institutional features are briefly introduced in Table 1 . The institutions in Table 1 are not an exhaustive list of institutions in the global renewable energy field, but are used as illustrative examples of different types of institutions governing the renewable energy field. While there are many institutions active in the renewable energy field from the NGO-network World Council for Renewable Energy to institutions such as the G7 and G20, the overview below focuses on prominent institutions at the international level with permanent secretariat and staff to comparatively illustrate differences in institutional features among such institutions. ${ }^{48}$

These institutions show both similarities and differences in their institutional features that can reasonably be expected to affect stakeholder's perceptions of their legitimacy. They particularly have notable differences when it comes to mandate and aim (purpose), inclusion and decisionmaking practices (procedure), and types of outputs (performance). First, in terms of mandate and aim, the UNFCCC and International Energy Agency (IEA) stand out as different to the others since they have a broader mandate than focusing primarily on renewable energy. The International Renewable Energy Agency (IRENA) and the Renewable Energy Policy Network for the 21st Century (REN21) also stand out with their explicit focus on promoting renewable energy. Second, when it comes to inclusion, while the IEA and the Clean Energy Ministerial (CEM) are minilateral institutions that are exclusive in terms of membership, both IRENA and the UNFCCC are open to any state that is a member of the UN, and they both have most of the countries in the world listed as members. Moreover, REN21 and Sustainable Energy for

\footnotetext{
${ }^{42}$ Sanderink, 'Renewable energy'.

${ }^{43}$ Sanderink et al., 'Mapping the institutional complex of the climate-energy nexus'.

${ }^{44}$ Sanderink, 'Renewable energy'.

${ }^{45}$ Sanderink et al., 'Mapping the institutional complex of the climate-energy nexus'; Lisa Sanderink and Naghmeh Nasiritousi, 'How institutional interactions can strengthen effectiveness: The case of multi-stakeholder partnerships for renewable energy', Energy Policy, 141 (2020).

${ }^{46}$ Sanderink, 'Renewable energy'.

${ }^{47}$ Naghmeh Nasiritousi and Soetkin Verhaegen, 'Disentangling legitimacy: Comparing stakeholder assessments of five key climate and energy governance institutions', in Zelli et al. (eds), Governing the Climate-Energy Nexus, pp. 183-211; Sanderink, 'Renewable energy'; Sanderink and Nasiritousi, 'How institutional interactions can strengthen effectiveness'.

${ }^{48}$ Thus, we expect these institutions to feature in the survey results, along with many other institutions and governance arrangements that also operate in the institutionally complex landscape of global renewable energy governance.
} 
Table 1. Prominent institutions in global renewable energy governance.

\begin{tabular}{|c|c|c|c|c|c|c|c|}
\hline Institution & Type of institution & Founded & Mission & Members & $\begin{array}{l}\text { Involvement of non-state } \\
\text { actors }\end{array}$ & Main activities & $\begin{array}{l}\text { Decision-making } \\
\text { processes }\end{array}$ \\
\hline $\begin{array}{l}\text { International } \\
\text { Energy Agency }\end{array}$ & $\begin{array}{l}\text { Inter-governmental } \\
\text { organisation }\end{array}$ & 1974 & $\begin{array}{c}\text { To ensure reliable, } \\
\text { affordable, and clean } \\
\text { energy. }\end{array}$ & $\begin{array}{l}30 \text { OECD member } \\
\text { states. }\end{array}$ & $\begin{array}{l}\text { No formal role but open for } \\
\text { participation. }\end{array}$ & $\begin{array}{l}\text { Knowledge production, } \\
\text { capacity building. }\end{array}$ & $\begin{array}{l}\text { Voting. Equal or weighted } \\
\text { votes depending on the } \\
\text { issue. }\end{array}$ \\
\hline $\begin{array}{l}\text { United Nations } \\
\text { Framework } \\
\text { Convention on } \\
\text { Climate } \\
\text { Change }\end{array}$ & $\begin{array}{l}\text { Inter-governmental } \\
\text { organisation }\end{array}$ & 1992 & $\begin{array}{c}\text { Prevent dangerous } \\
\text { anthropogenic climate } \\
\text { change. }\end{array}$ & $\begin{array}{c}\text { Almost all states in } \\
\text { the world. }\end{array}$ & $\begin{array}{l}\text { Participation in UNFCCC } \\
\text { conferences and other } \\
\text { initiatives and activities. }\end{array}$ & $\begin{array}{l}\text { Concluding international } \\
\text { agreements on climate } \\
\text { change, information } \\
\text { sharing, capacity } \\
\text { building. }\end{array}$ & Consensus. \\
\hline $\begin{array}{l}\text { International } \\
\text { Renewable } \\
\text { Energy Agency }\end{array}$ & $\begin{array}{l}\text { Inter-governmental } \\
\text { organisation }\end{array}$ & 2009 & $\begin{array}{l}\text { Promote renewables to } \\
\text { achieve sustainable } \\
\text { and secure energy } \\
\text { access and economic } \\
\text { growth. }\end{array}$ & $\begin{array}{l}162 \text { member states } \\
\text { and } 21 \text { states in } \\
\text { accession. }\end{array}$ & $\begin{array}{l}\text { Participation in } \\
\text { knowledge-sharing } \\
\text { activities. }\end{array}$ & $\begin{array}{l}\text { Knowledge production } \\
\text { and dissemination, } \\
\text { capacity building, } \\
\text { mobilising resources. }\end{array}$ & $\begin{array}{l}\text { Consensus or majority } \\
\text { depending on the issue. } \\
\text { One vote per member } \\
\text { state. }\end{array}$ \\
\hline $\begin{array}{l}\text { Clean Energy } \\
\text { Ministerial }\end{array}$ & $\begin{array}{l}\text { Inter-governmental } \\
\text { organisation }\end{array}$ & 2009 & $\begin{array}{l}\text { Unite its members in } \\
\text { efforts to increase } \\
\text { energy efficiency, clean } \\
\text { energy supply, and } \\
\text { clean energy access. }\end{array}$ & 28 member states. & $\begin{array}{l}\text { Non-state actors are } \\
\text { encouraged to engage with } \\
\text { CEM and its members, for } \\
\text { example through } \\
\text { workshops. }\end{array}$ & $\begin{array}{l}\text { As a forum for } \\
\text { collaboration CEM } \\
\text { connects its members } \\
\text { and lets them proceed } \\
\text { with initiatives and } \\
\text { invite others to join. }\end{array}$ & $\begin{array}{l}\text { No formal decisions are } \\
\text { taken. Member states are } \\
\text { free to join initiatives or to } \\
\text { abstain. }\end{array}$ \\
\hline $\begin{array}{l}\text { Renewable } \\
\text { Energy Policy } \\
\text { Network for } \\
\text { the 21st } \\
\text { Century }\end{array}$ & $\begin{array}{l}\text { Multi-stakeholder } \\
\text { partnership }\end{array}$ & 2004 & $\begin{array}{l}\text { Contribute to } \\
\text { renewable energy } \\
\text { transition by making } \\
\text { data on renewables } \\
\text { available. }\end{array}$ & $\begin{array}{l}\text { More than } 70 \\
\text { members from } \\
\text { government, } \\
\text { business, } \\
\text { academia, NGOs, } \\
\text { and IOs. }\end{array}$ & $\begin{array}{c}\text { States, business, academia, } \\
\text { NGOs, and other IOs are } \\
\text { equally represented as } \\
\text { members. }\end{array}$ & $\begin{array}{l}\text { Collecting information } \\
\text { on renewable energy } \\
\text { from its members, } \\
\text { processing it, and } \\
\text { making it available to } \\
\text { the public. }\end{array}$ & Consensus is the norm. \\
\hline $\begin{array}{l}\text { Sustainable } \\
\text { Energy for All }\end{array}$ & $\begin{array}{l}\text { Multi-stakeholder } \\
\text { partnership }\end{array}$ & 2011 & $\begin{array}{l}\text { Increase energy } \\
\text { efficiency, energy } \\
\text { access, and renewable } \\
\text { energy diffusion } \\
\text { globally. }\end{array}$ & $\begin{array}{c}\text { Around } 80 \text { different } \\
\text { types of } \\
\text { organisations. }\end{array}$ & $\begin{array}{l}\text { Multi-stakeholder } \\
\text { partnership, open to } \\
\text { different kinds of } \\
\text { organisations. }\end{array}$ & $\begin{array}{l}\text { SEforALL provides a } \\
\text { platform for } \\
\text { collaboration and } \\
\text { produces and } \\
\text { disseminates } \\
\text { knowledge. }\end{array}$ & $\begin{array}{l}\text { Decisions are made by the } \\
\text { Administrative Board, with } \\
\text { input from the Funder's } \\
\text { Council representing the } \\
\text { funding partners. }\end{array}$ \\
\hline
\end{tabular}

Sources: CEM (Clean Energy Ministerial), 'About the Clean Energy Ministerial' (2009), available at: \{www.cleanenergyministerial.org/about-clean-energy-ministerial\}; IEA (International Energy Agency), 'About'

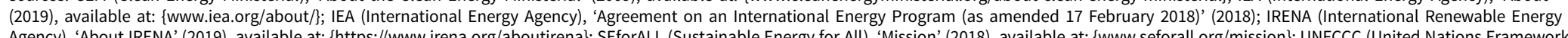

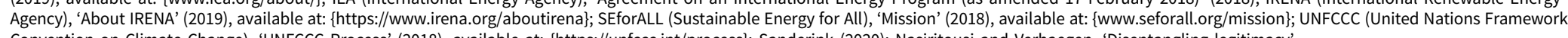
Convention on Climate Change), 'UNFCCC Process' (2018), available at: \{https://unfccc.int/process\}; Sanderink (2020); Nasiritousi and Verhaegen, 'Disentangling legitimacy'. 
All (SEforALL) are multi-stakeholder partnerships with both states and non-state actors as members. IRENA, IEA, CEM, and UNFCCC, on the other hand, exclusively have states as their members. Even if they all engage non-state actors in their activities, they are not represented as formal members. Out of the intergovernmental organisations, the UNFCCC stands out as the institution with the most and closest collaborations with non-state actors as it has extensive practices for involving non-Party stakeholders in different activities. ${ }^{49}$

Third, the decision-making processes are different between the six institutions. The UNFCCC employs consensus, which gives the same weight to every member when it comes to formal decision-making. In IRENA, voting weights are also equal, but some decisions are based on majority voting rather than on consensus. REN21 resembles IRENA as each stakeholder group has the same number of votes and as it employs either majority or consensus depending on the issue. The IEA employs the same model of both consensus and majority voting as IRENA and REN21, but voting rights are either equal or weighted in accordance with its founding document, depending on the issue. CEM and SEforALL, on the other hand, act as platforms for collaboration and their members are free to join initiatives by their own choosing.

Finally, the institutions also differ with respect to their core activities and outputs. While they all engage in the production and dissemination of knowledge to some degree, REN21 is specialised in collecting and presenting data. IRENA and IEA do a great amount of knowledge-related work as well, as well as being engaged in capacity building. CEM and SEforALL are first and foremost acting as collaboration platforms, and the initiatives that come out of them can fulfill various functions. The UNFCCC, lastly, is primarily a forum for negotiating international climate agreements, even though its conferences also act as spaces for collaboration and knowledge sharing. ${ }^{50}$

The article explores below how these similarities and differences between global renewable energy institutions affect the perceptions of stakeholders on which of them that are most legitimate.

\section{Theory-based expectations about most legitimate institutions}

Global energy institutions have traditionally suffered from low legitimacy, ${ }^{51}$ although individual institutions in this field have generally not faced the same legitimacy crises as international institutions in other governance fields. ${ }^{52}$ With the race to promote renewable energy as a way to address climate change becoming more urgent, both collaboration and competition between different institutions in the field have been noted. ${ }^{53}$ With a multitude of institutions seeking to promote renewable energy globally, which one could we expect to be considered most legitimate by stakeholders in renewable energy governance? In the following section we outline a number of expectations derived from previous literature. The aim is not to test the expectations, but rather to make theoretical contributions to the field.

While several institutions perform similar functions in terms of promoting renewable energy globally, they differ in terms of purpose, procedure, and performance. According to Lenz and

\footnotetext{
${ }^{49}$ Nasiritousi and Verhaegen, 'Disentangling legitimacy'.

${ }^{50}$ Naghmeh Nasiritousi, Shapers, Brokers and Doers: The Dynamic Roles of Non-State Actors in Global Climate Change Governance, Linköping Studies in Arts and Science, No. 667 (Linköping: Linköping University Press, 2016).

${ }^{51}$ Karlsson-Vinkhuyzen, 'The legitimation of global energy governance'.

${ }^{52}$ See also Klaus Dingwerth et al., International Organizations Under Pressure: Legitimating Global Governance in Challenging Times (Oxford: Oxford University Press, 2019).

${ }^{53}$ Thijs Van de Graaf, 'Fragmentation in global energy governance: Explaining the creation of IRENA', Global Environmental Politics, 13:3 (2013), pp. 14-33; Federico Esu and Francesco Sindico, 'IRENA and IEA: Moving together towards a sustainable energy future - Competition or collaboration?', Climate Law, 6: 3-4 (2016), pp. 233-49; Indra Overland and Gunilla Reischl, 'A place in the sun? IRENA's position in the global energy governance landscape', International Environmental Agreements: Politics, Law and Economics, 18:3 (2018), pp. 335-50; Sanderink and Nasiritousi, 'How institutional interactions can strengthen effectiveness'.
} 
Viola, ${ }^{54}$ older institutions are more well established and therefore have a clear and well-recognised identity and can thus be expected to enjoy higher legitimacy. From the institutions mentioned above, it would imply that the IEA would be seen as the most legitimate of the institutions working to promote renewable energy. The IEA, however, does not have promoting renewable energy as its core mission. In fact, it was the IEA's predominant focus on other energy sources (primarily fossil fuels) that lead to the creation of IRENA. ${ }^{55}$ The IEA has however since the creation of IRENA adapted its work to also focus on renewables. ${ }^{56}$ Nevertheless, in terms of purpose, it may be that IRENA has an advantage despite being a relatively new institution. IRENA's core mission is to promote renewable energy, and as it also has near universal membership, it can be expected to be considered the most legitimate institution in global renewable energy governance. On the other hand, IRENA has been criticised for mostly acting as a talk shop without much action on the ground. In terms of performance, therefore, other institutions may have greater advantages. It may be, for example, that an institution like the CEM, which is more focused on taking action on clean energy, is considered most legitimate if stakeholders value output dimensions over input dimensions. CEM is however a minilateral institution without deep non-state actor participation. In an era where non-state participation is considered an important feature of legitimate procedure, ${ }^{57}$ it may be that multi-stakeholder institutions such as REN21 or SEforALL are considered more legitimate, particularly among non-state actors. The institution that is relatively strong on both input and output dimensions is the UNFCCC, with its nearuniversal membership, transparency provisions, deep non-state actor engagement, and outputs such as the Kyoto Protocol and the Paris Agreement. ${ }^{58}$ However, as is the case with the IEA, the UNFCCC does not primarily focus its activities on promoting renewable energy. Moreover, as the Paris Agreement has shown, there is a domestic logic to the implementation of climate and energy policies and therefore stakeholders may see not the international or transnational level, but the state or local level as the location of the most legitimate institutions.

The discussion above highlights two things: which institution in global renewable energy governance that is considered to be most legitimate is dependent on whether stakeholders value purpose, procedure, or performance more, and that legitimacy perceptions could differ between different types of stakeholders. Building on the study by Naghmeh Nasiritousi and Soetkin Verhaegen, ${ }^{59}$ we expect legitimacy perceptions to vary depending on: (1) the type of stakeholder (governmental or non-governmental); (2) their area of work (if the work primarily with mitigation, adaptation, development, technology etc.); and (3) geographical origin (world region or income-level of country). These are expected to be proxies for the norms, values, and experiences held by different stakeholder groups and thus shape their legitimacy beliefs. While these factors are believed to affect perceptions, it is beyond the scope of this article to examine why stakeholders hold the perceptions that they do. Here, we focus on how perceptions differ between stakeholders and thus we leave the question of why they differ to future research. With these general expectations in mind, we now turn to our empirical material.

\section{Data and methods}

In order to gauge the views of stakeholders familiar with global renewable energy institutions, we employed a questionnaire that targeted climate and energy experts. To this end, the survey was

\footnotetext{
${ }^{54}$ Lenz and Viola, 'Legitimacy and institutional change in international organisations'.

${ }^{55}$ Van de Graaf, 'Fragmentation in global energy governance'.

${ }^{56}$ Harald Heubaum and Frank Biermann, 'Integrating global energy and climate governance: The changing role of the International Energy Agency', Energy Policy, 87 (2015), pp. 229-39.

${ }^{57}$ Jonas Tallberg et al., 'Explaining the transnational design of international organizations', International Organization, 68 (2014), pp. 741-74.

${ }^{58}$ Nasiritousi and Verhaegen, 'Disentangling legitimacy'.

${ }^{59}$ Ibid.
} 
distributed to participants at three venues: the $23^{\text {rd }}$ Conference of Parties of the UNFCCC in Bonn, Germany, November 2017; the UNFCCC intersessional meeting in Bonn, Germany, May 2018; and the Nordic Clean Energy Week that comprised both Mission Innovation and CEM meetings in Malmö, Sweden, and Copenhagen, Denmark, May 2018. At the UNFCCC meetings we handed out questionnaires in side events with an energy-related focus. In this way, we obtained responses from a wide variety of stakeholders, including representatives from national, regional, and local governments, businesses, NGOs, academia, and intergovernmental organisations. To complement the paper survey, we also launched a web-based questionnaire to target specific categories of respondents that were not adequately represented in the paper version. Nevertheless, the results should not be seen as generalisable but rather as a first step towards better understanding perceptions of legitimacy among global climate and energy stakeholders.

The questionnaire - the CLIMENGO Expert Survey - was part of a research project that examines issues of legitimacy and effectiveness in global climate and energy governance. It therefore included some questions that were not used in the research presented in this article. All of these questions were placed later in the questionnaire and should not affect our results. Three open questions were posed to capture different dimensions of legitimacy. First respondents were asked which institution for promoting renewable energy globally that they considered to be the most effective and to specify why, thereafter which institution that they considered to be the most legitimate and to specify why, and thirdly which institution that they had the most confidence in, and why. By posing these open questions, we let the respondents themselves interpret the concepts in question. It was clarified in the questionnaire that institutions could include any kind of governance arrangement, ranging from IOs, collaborations between private businesses, and NGOs, as well as public-private partnerships. No other statements that should affect the respondent's answers were made in the questionnaire.

It should be noted that this study does not aim to measure overall levels of legitimacy for institutions in global renewable energy governance. Neither are the open questions posed to rank institutions based on their levels of legitimacy. Instead we are interested in understanding which institutions are widely held by climate and energy experts to be highly legitimate and why. Those institutions that are frequently mentioned by respondents are identified as being widely seen as highly legitimate, while those that receive fewer mentions do not necessarily suffer legitimacy challenges, but are generally not viewed as highly legitimate by respondents. As such, the study is more of a mapping of perceptions of legitimacy among global climate and energy stakeholders rather than a systematic assessment of legitimacy in global renewable energy governance.

By asking about effectiveness, we make the respondents think about output dimensions of legitimacy. The word legitimacy is in many ways a normative word that in global environmental governance historically has been associated with democratic legitimacy, whereby input features such as inclusion, transparency, and accountability have been emphasised as being important for legitimate institutions. ${ }^{60}$ By asking directly about legitimacy, we expect stakeholders to think of these input sides of legitimacy. Finally, by asking about confidence we seek to find out how the respondents answer on a supposedly neutral question that is often used to measure legitimacy. By asking three questions, two of which are biased towards procedure and performance respectively, we can compare the results from all three questions to each other and get a better understanding of how the way legitimacy is measured affects the results.

The questions were open in the sense that the questionnaire did not present respondents with predefined categories. Instead, respondents had to fill in their own replies. This made coding of the questionnaires time consuming, but it gave us the advantage of high sensitivity in relation to the empirical reality, as the respondents could choose freely which institution to indicate and state their own reasons for doing so. This was particularly important to us since the study concerned

\footnotetext{
${ }^{60}$ Bernstein, 'Legitimacy in intergovernmental and non-state global governance'.
} 
stakeholder's views on legitimacy in the sociological sense, and not our own normative or theoretical views on legitimacy as political scientists. Thus, asking open questions had the advantage of keeping our inquiry open for the possibility that properties unrelated to performance and procedure might be important for legitimacy perceptions.

After collecting the answers, the questionnaires were coded into a dataset using Microsoft Excel. We noted that some of the key institutions identified in our literature review were among the most frequently mentioned and were thus coded into a separate category, while other institutions (all much less frequently mentioned) were coded as part of larger categories, such as 'other intergovernmental organizations'. Answers about why they mentioned that particular institution were coded using categories derived from a review of the sources of legitimacy. ${ }^{61}$ We coded answers into three categories (purpose, procedure, and performance) as well as the following sub-categories: Mandate, capabilities, and aim/focus for purpose; transparency, accountability, inclusion, procedural fairness, non-bias, and collaboration for procedure; and output, outcome, impact, distributional fairness, and expertise for performance. In other words, answers pertaining to the internal properties of the institution were coded as purpose, organisational properties procedure, and instrumental properties as performance. Since these are broad categories, our coding strategy was to also include ambiguous answers in what we thought was the most reasonable interpretation of the answers, using our experience of the issue-areas and the language used in them.

The coding thus involved a degree of interpretation by us as researchers. In order to ensure inter-coder reliability, both authors checked every single answer that the other one had coded. Whenever we made different interpretations, we both looked at the answer in question and discussed the appropriate coding of it. As a side effect, this also means that we have double-checked every single answer for simple errors.

After coding the questions, we did a final coding where we indicated whether respondents had stated the same institution on the three different questions (that is, the same institution being most effective, legitimate, and having most confidence in), or if they had stated different institutions. Respondents who had not provided answers on all questions were placed in a third category.

Respondents were also asked to indicate which type of organisation that they represented, the issue-area that their work was focused on, and their nationality. Nationality was coded into world regions by using the UN's regional groups, as well as into income groups by using the World Bank's income categories of countries. Based on these categories, our sample looks as follows: We obtained a total of 262 filled in questionnaires. Twenty-two per cent of the respondents were national government, 25 per cent NGO, 20 per cent academia, 15 per cent business, 7 per cent intergovernmental organisation representatives, and 11 per cent defined themselves as other, including parliamentarians, local government representatives, and journalists. In terms of issue-areas that respondents work with, most cited multiple issues, but in terms of frequencies it looks as follows: 20 per cent work on mitigation, 17 per cent on technology, 12 per cent on energy security, 11 per cent on adaptation, 11 per cent on development, 7 per cent on finance, 4 per cent on carbon markets, and 18 per cent on other issues, including community energy, health, and energy efficiency. In terms of world region, 65 per cent of respondents come from the European and other group, which includes the European countries, the US, Canada, Australia, and Turkey. Fifteen per cent come from the Asia-Pacific group, 14 per cent from the African group, and 6 per cent from the Latin American and Caribbean group. In terms of income categories, 70 per cent come from a high-income country, 13 per cent from an uppermiddle income country, 13 per cent from a lower-middle income country, and 4 per cent from a low-income country. These were coded into two categories: one high-income category and the other including the three lower income categories, named low-income countries. We

\footnotetext{
${ }^{61}$ Scholte and Tallberg, 'Theorizing the institutional sources of global governance legitimacy'; Nasiritousi and Verhaegen, 'Disentangling legitimacy'.
} 
thus have a sample of stakeholders that include respondents that work with the institutions as members, staff or observers, and some that do not work with the institutions but that may be affected by their work. Given the low $\mathrm{N}$ in certain groups when we disaggregate the data, we do not perform statistical analyses. Rather, in what follows we outline our results using descriptive statistics.

\section{Results}

Which institutions are most frequently cited as most effective, legitimate, and those that respondents have most confidence in, respectively? And which reasons are provided by respondents? In what follows, we present results from the survey to answer these questions. Thereafter we focus in on the answer to the confidence question, since this is the most common measure of legitimacy or support for an institution, to explore how answers to this question differ between different groups of stakeholders. ${ }^{62}$

Figure 1 shows the institutions that respondents answered on the three open questions about effectiveness, legitimacy, and confidence. A first striking result is that IRENA comes out strongly no matter how we ask. It gets the most mentions on all three questions (on average 25 per cent of the answers). The next frequently mentioned institutions are IEA and UNFCCC. Notable is the fact that CEM was mentioned so rarely that it is not represented in an own category, but was included in the category 'other intergovernmental institutions' together with institutions such as the G20 and the Global Green Growth Institute. Interesting to note is also that partnerships (often simply mentioned as PPPs or sometimes specifically named, such as the Global 100\% Renewable Energy Platform) are mentioned frequently on the effectiveness question (13 per cent), but less so on the legitimacy and confidence questions ( 3 per cent and 6 per cent, respectively). The opposite pattern is shown for UNFCCC, where it is less frequently mentioned on the effectiveness question ( 5 per cent) compared to the legitimacy and confidence questions (11 per cent and 9 per cent, respectively).

On the whole, the picture that emerges is one where many types of institutions are considered relevant in global renewable energy governance. In fact, 20 per cent of answers mention multiple institutions, and some explicitly write that many are relevant and therefore not one can be singled out. A few respondents (1 per cent) hold the opposite view and state that they do not have confidence in any institution that promote renewable energy globally, and that none are legitimate or effective. A general pattern that can be seen in the data is that intergovernmental institutions enjoy the greatest level of legitimacy in global renewable energy governance, much greater than multi-stakeholder partnerships and other actors.

Interestingly, 47 per cent of respondents who filled in all three questions answered the same institutions for effectiveness, legitimacy, and confidence. The reasons for choosing those institutions, however, sometimes differed across the three questions. Turning now to the sources of legitimacy, the results show that there are clear differences in reasons provided by respondents when asked about most effective institution, the most legitimate institution, and when asked about the institution that they have most confidence in.

Figure 2 shows our coding of the open answers into the three categories purpose, procedure, and performance. A notable finding is that no matter how we ask, performance stays important. That performance is dominant on the effectiveness question is not very surprising (53 per cent answered performance, 30 per cent purpose, and 16 per cent procedure). However, even on

\footnotetext{
${ }^{62}$ By posing open questions in different ways, this article has highlighted that legitimacy may be difficult to capture in a single survey question. Nevertheless, because legitimacy is a multidimensional concept we elect to focus on confidence as it captures the various dimensions of why a stakeholder may have confidence in, and ultimately support, an institution. Effectiveness is too much geared toward output dimensions of legitimacy, and the term legitimacy is often associated with achieving democratic standards (Bernstein, 'Legitimacy in intergovernmental and non-state global governance'), and may therefore be interpreted as legitimacy in a normative rather than sociological sense, which is why we elect to focus on the confidence question in the stakeholder analysis. Having said this, future empirical work is needed to determine how the different dimensions of legitimacy can best be captured in surveys.
} 


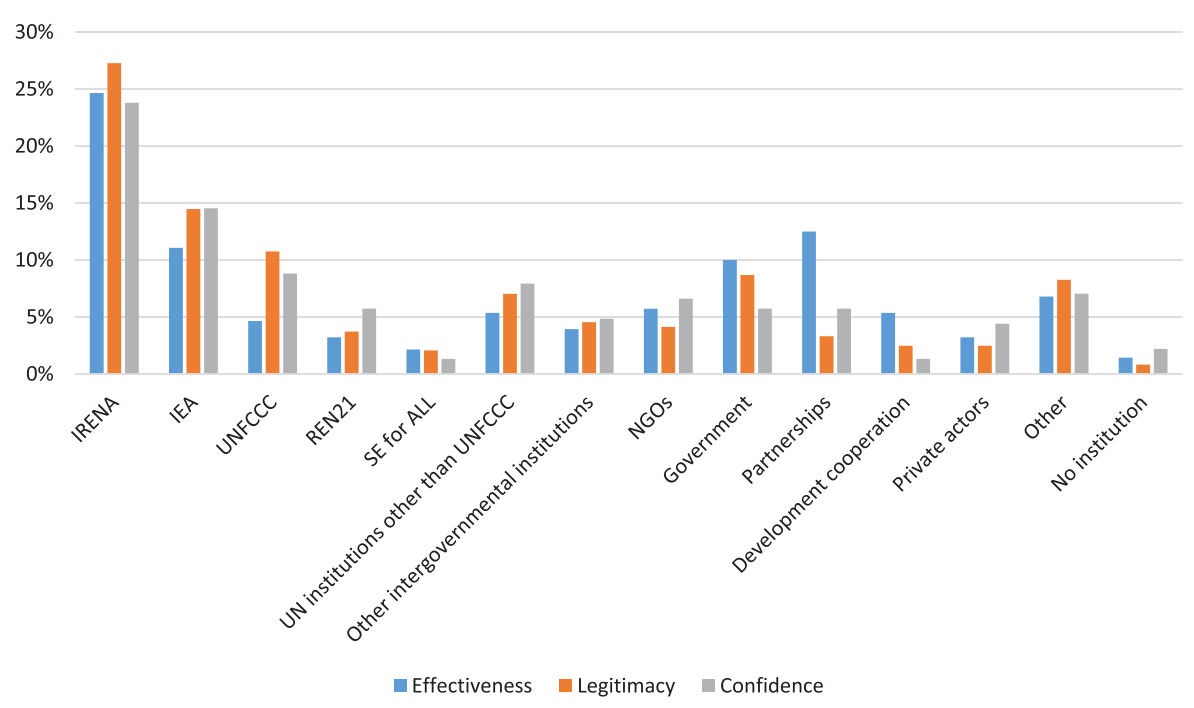

Figure 1. Institutions mentioned in answers to questions about effectiveness, legitimacy, and confidence as a percentage of total answers.

Figure 2. Reasons for highlighting an institution as most effective, most legitimate, or most confidence in.

\section{Sources of legitimacy}

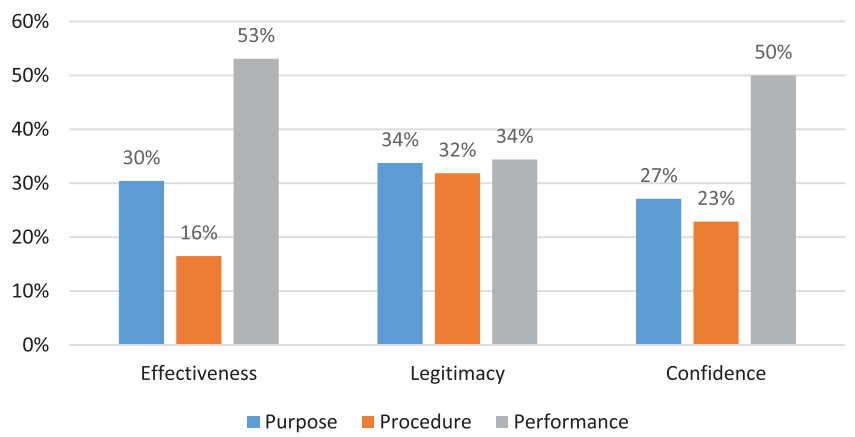

the legitimacy question, where we expected reasons provided by participants to be related to procedure, respondents stated reasons related to performance as much as reasons related to purpose and procedure (32 per cent answered procedure, 34 per cent purpose, and 34 per cent performance). On the confidence question, performance was almost stated more than procedure and performance combined (50 per cent answered performance, 27 per cent procedure, and 27 per cent purpose). Thus, from an overall assessment, performance can be argued to be the most important source of legitimacy in global renewable energy governance as it scores high (either highest or in a shared first position) no matter how we ask.

Moreover, the purpose of an institution turned out to be a significant source of its legitimacy, on par with procedure. That around one-third of answers mentioned purpose on all three questions indicates that among key stakeholders in global renewable energy governance, the purpose of an institution is an important source of legitimacy. In contrast to much of the previous literature on legitimacy that only focuses on procedure and performance, ${ }^{63}$ our results show that at least under institutional complexity, purpose also matters.

\footnotetext{
${ }^{63}$ Dellmuth and Tallberg, 'The social legitimacy of international organizations'; Bernauer et al., 'Do citizens evaluate international cooperation'; Dellmuth et al., 'Institutional sources of legitimacy for international organisations'.
} 


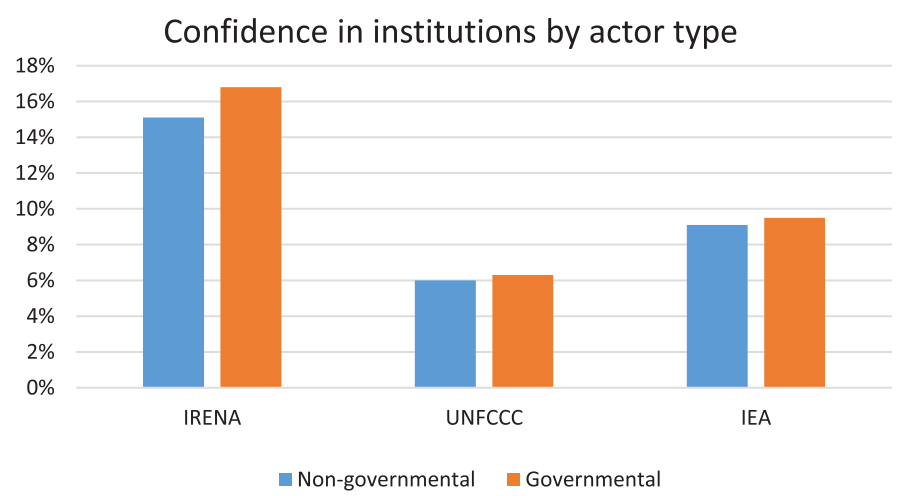

Figure 3. Share of responses within each actor type (non-governmental actor or governmental actor) mentioning IRENA, UNFCCC, and IEA on the confidence question.

Our sub-categorisations of answers provide a more fine-grained analysis of what the sources of legitimacy are for these institutions. The performance category is dominated by answers that pertain to the institution's output, and to a lesser extent outcome. Examples of answers include good data, quality research, project financing, and technology development and dissemination. The purpose category is dominated by an institution's aim, focus of work, mandate, and capabilities in terms of staff and resources. Examples here include having a mandate to promote all renewable technologies, having an international and narrow focus of work, and having access to resources, such as financial and political capital. The procedure category is dominated by answers related to inclusion, collaboration, and non-bias. Examples include the institution's inclusion of relevant actors (with an emphasis on universal institutions) and openness to collaborations, as well as being independent institutions without conflicts of interest.

In sum, the results show that institutions involved in global renewable energy governance draw legitimacy from several sources and that the sources that the normative literature identify as important for legitimacy (such as transparency and accountability) might not be the ones that stakeholders identify when evaluating institutions. On the whole, the survey shows that IRENA is considered the most effective and legitimate institution and that most have confidence in. The reasons for mentioning IRENA vary but generally include its universal membership, a mandate that focuses on renewables, its data and expertise, broad outreach, and project work that focuses on all renewable technologies in different countries. In an institutionally complex governance landscape, the purpose and identity of the institution thus matters for perceptions of legitimacy.

Next, we provide an overview of how different categories of respondents have answered on the confidence question. We focus on the confidence question (rather than effectiveness or legitimacy) since this is the common term used in the literature for measuring legitimacy and is not biased towards either input or output legitimacy. First, we examine the extent to which different categories of respondents cite the three most frequently mentioned institutions (IRENA, IEA, and UNFCCC) in our dataset. Then we examine how the sources of confidence differ between categories of respondents. Given the low number of respondents in certain categories, the figures are purely descriptive, and patterns would need to be confirmed in future studies. Nevertheless, they provide a first indication of how different groups of actors may perceive institutions differently in terms of how much confidence they have in them.

Figure 3 shows the share of responses within each actor type mentioning IRENA, UNFCCC, and IEA on the confidence question. Interestingly, there are few differences in how governmental and non-governmental respondents mention the three institutions on the confidence question. Perhaps this is a reflection of the non-governmental category being a mix of different actors such as businesses, NGOs, academics, and others, thereby hiding differences between different groups of non-governmental actors. 
Figure 4. Share of responses within each category of issue-area of work mentioning IRENA, UNFCCC, and IEA on the confidence question.

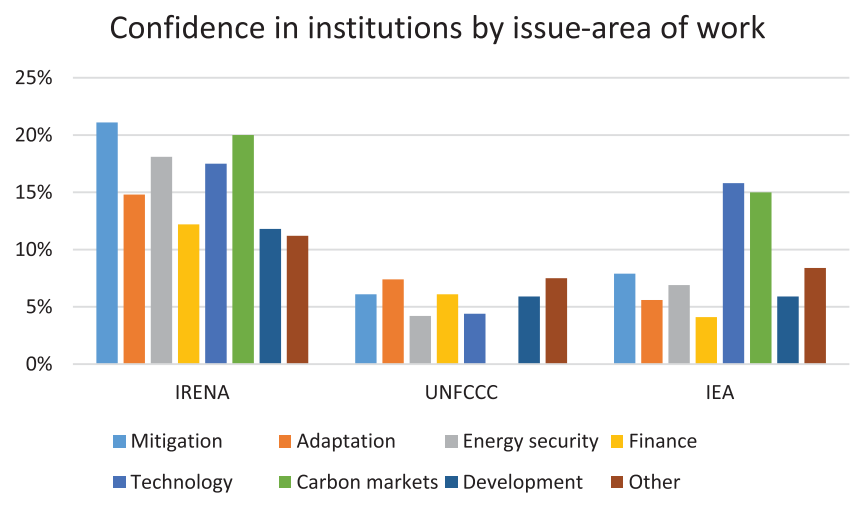

Figure 5. Share of responses within each country group mentioning IRENA, UNFCCC, and IEA on the confidence question.

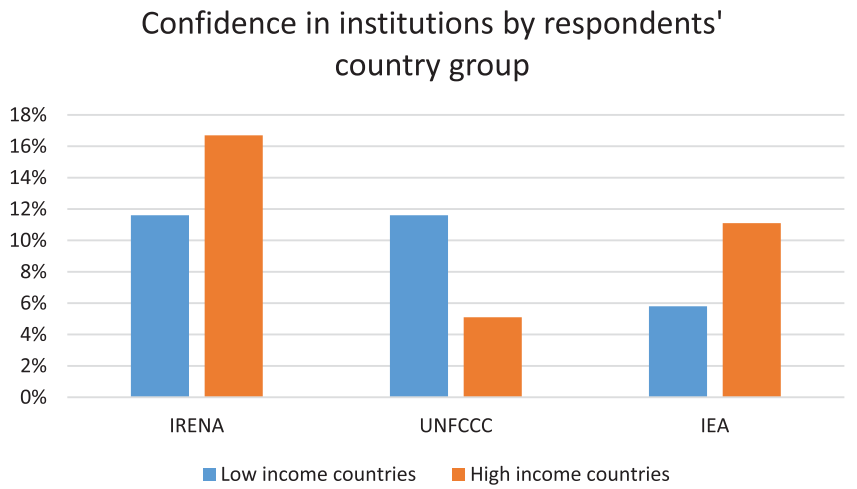

If we instead divide up answers depending on the issue-area of work that the respondent is primarily focusing on, we see starker differences. In particular, those working on carbon markets and technology issues appear to have greater confidence in the IEA than those working on other issue-areas.

Figure 5 indicates that high-income countries have more confidence in IRENA and the IEA and less confidence in the UNFCCC for promoting renewable energy compared to low-income countries.

Figure 6 indicates that IRENA enjoys confidence across all world regions, but particularly from the European and Others group and the Latin American and Caribbean group. The UNFCCC is mostly mentioned by respondents from the African group and the Latin American and Caribbean group. The IEA on the other hand is mentioned most by respondents from the European and Others group and the Asia-Pacific group.

These findings indicate that a wide set of climate and energy experts have confidence in IRENA but that confidence in the IEA and the UNFCCC for promoting renewable energy vary more depending on the background of respondents. Since the norms, values, and experiences of respondents differ, systematic differences in confidence in institutions was expected. ${ }^{64}$ This is however the first study that to our knowledge examines these differences in confidence among climate and energy experts and the findings show both interesting similarities as well as differences between how groups of respondents view confidence in institutions.

Finally, we turn to the question of how different actor categories describe why they have confidence in renewable energy institutions. Figure 7 shows the share of responses within each actor

\footnotetext{
${ }^{64}$ See also Nasiritousi and Verhaegen, 'Disentangling legitimacy'.
} 
Confidence in institutions by respondents'

geographical region

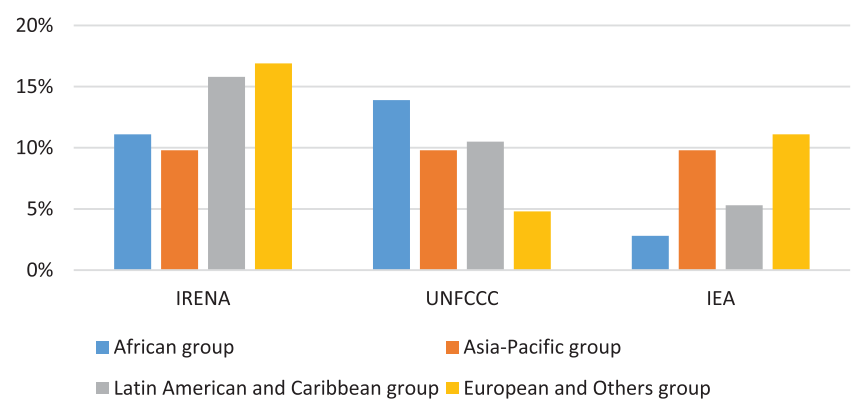

Sources of confidence by actor type

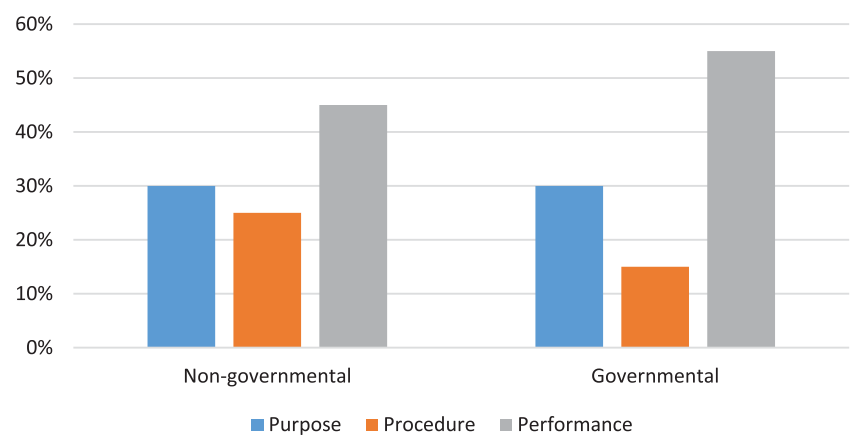

Figure 6. Share of responses within each geographical region mentioning IRENA, UNFCCC, and IEA on the confidence question.
Figure 7. Share of responses within each actor type mentioning purpose, procedure, and performance on the confidence question.

\section{Sources of confidence by issue-area of work}

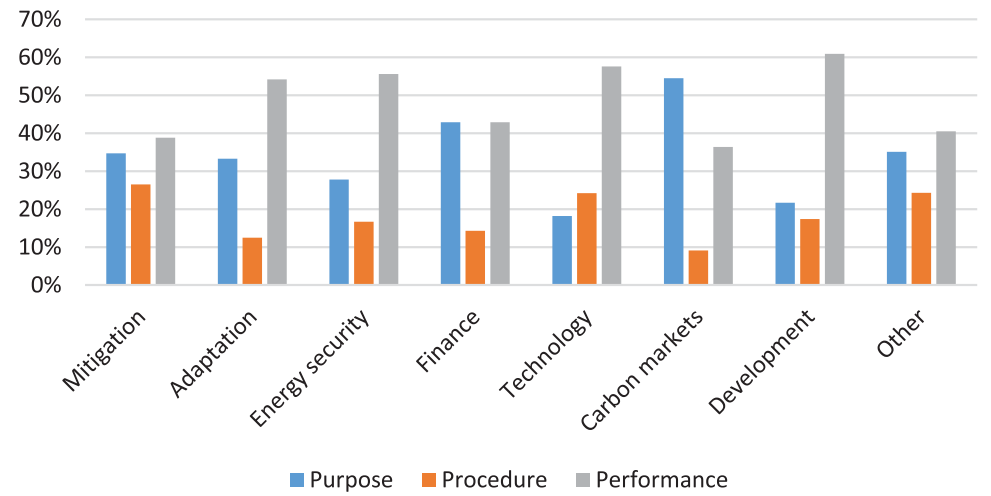

Figure 8. Share of responses within each category of issue-area of work mentioning purpose, procedure, and performance on the confidence question.

type mentioning purpose, procedure, and performance on the confidence question. While governmental and non-governmental respondents mention purpose to the same extent, governmental respondents mention performance slightly more and procedure slightly less than non-governmental respondents.

Figure 8 shows that nearly all categories of respondents most frequently cite performance, then purpose then procedure as sources of confidence, with the exception of those primarily working 
Figure 9. Share of responses within each country group mentioning purpose, procedure, and performance on the confidence question.

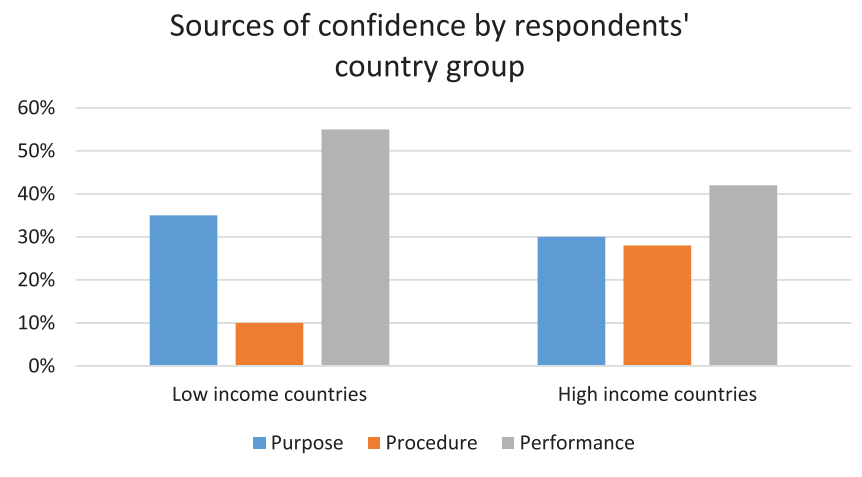

Figure 10. Share of responses within each geographical region mentioning purpose, procedure, or performance on the confidence question.

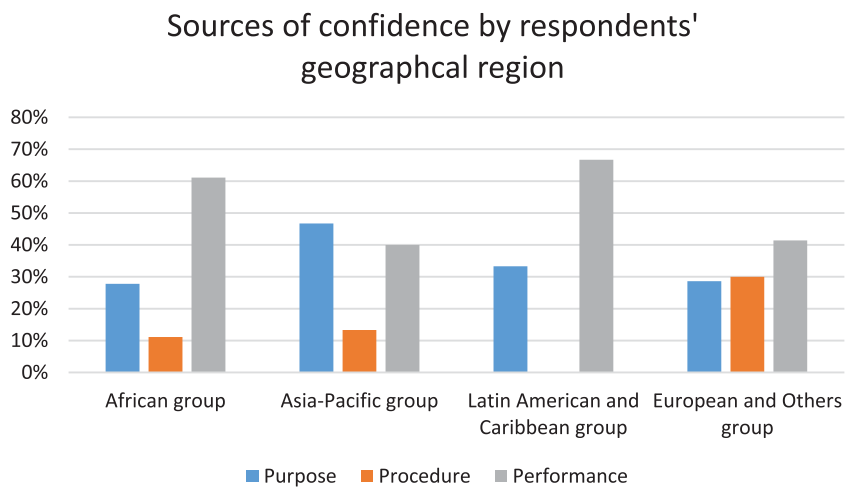

with technology issues; they cite procedure slightly more than purpose. The procedural issues that they cite are mostly related to the non-bias and transparency of institutions, and the inclusion of relevant actors.

Figure 9 shows that procedural reasons are provided primarily by respondents from highincome countries, while performance is slightly more mentioned by respondents from lowincome countries.

Figure 10 shows that while purpose, procedure, and performance are mentioned to about the same extent by respondents from the European and Other category of countries, procedure is very rarely mentioned by respondents from the other world regions. Interestingly, purpose is mentioned slightly more by respondents from the Asia-Pacific group. This group of respondents frequently cite for example resources and mandate as a reason for confidence in an institution.

The data thus shows the same overall pattern of performance being the most mentioned source of confidence among climate and energy experts, with a few exceptions. Respondents from all backgrounds frequently cite the data, reports, and initiatives of institutions as a source of confidence. This of course does not mean that other less cited sources of confidence, such as transparency or accountability, are not important. Rather, the results may indicate that in a complex governance landscape where several institutions have overlapping functions, it is performance that constitutes the ultimate source of confidence among stakeholders. Of course, strong performance is likely to depend on the purpose and procedure of the institution, ${ }^{65}$ so the key for institutions to enjoy legitimacy may be appropriate purpose and procedure for fulfilling adequate performance according to a range of stakeholders.

\footnotetext{
${ }^{65}$ Andresen and Hey, 'The effectiveness and legitimacy of international environmental institutions'.
} 


\section{Conclusions}

The legitimacy of international institutions has in recent years received growing interest from scholars, yet analyses of stakeholder perceptions of the legitimacy of institutions that coexist within a governance field have been few in number. ${ }^{66}$ Given the proliferation of institutions in the field of global climate and energy governance, this study focused on understanding how climate and energy experts from different stakeholder groups perceive the legitimacy of institutions promoting renewable energy. Through its unique survey approach, the article contributes with novel insights about stakeholder perceptions of legitimacy within global renewable energy governance. Specifically, the article makes three contributions to the existing literature. Theoretically, it unpacks the legitimacy concept and offers a multidimensional conception of legitimacy. Methodologically, it captures these different dimensions of legitimacy by relying on three open survey questions. Empirically, it maps legitimacy perceptions among climate and energy experts and not only shows which institutions are considered most legitimate, but also why they are considered legitimate and how this varies between different stakeholders.

The article presented four central results. First, our data finds that stakeholders view a multitude of institutions in global renewable energy governance as legitimate, but that IRENA has the broadest backing among climate and energy experts. IRENA was found to be most frequently cited on all of our measures: effectiveness, legitimacy, and confidence. Being globally mandated and visible, disseminating quality data and working on a wide range of renewable energy sources was frequently mentioned by respondents as a reason for answering IRENA.

Second, we found that performance is the dimension that is mentioned by most as a source of legitimacy. This indicates that performance is a key source of legitimacy in global renewable energy governance, which is in line with other studies of legitimacy of global governance institutions. ${ }^{67}$ However, in contrast to much of the literature on legitimacy that focuses only on procedure or performance, our data shows that purpose is also a strong source of legitimacy for global renewable energy governance institutions. When there exist institutions with similar functions yet different setups, the purpose and identity of the institutions are likely to matter as stakeholders evaluate the legitimacy of a set of alternative institutions. Thus, at least under institutional complexity, scholarly work on legitimacy should go beyond the procedure - performance discussion and include the purpose-related dimension as well.

Third, differences were found between how different categories of stakeholders perceive the institutions. In particular, our data indicates that a wide set of climate and energy experts have confidence in IRENA but that confidence in the IEA and the UNFCCC for promoting renewable energy vary more depending on the background of respondents. Thus, while the overall picture is one of agreement between different groups of stakeholders, our results also imply that legitimacy perceptions in global renewable energy governance may vary in systematic ways between different stakeholder groups. ${ }^{68}$

Fourth, the results clearly show that legitimacy appears to be primarily associated with state-led institutions. Overall, our results are aligned with those of Jonas Tallberg, ${ }^{69}$ who found that traditional forms of international institutions hold up better in terms of legitimacy than new types of transnational institutions. While multi-stakeholder institutions and private-public partnerships have proliferated in recent years, our data indicates that their legitimacy is generally not on the same level as those of intergovernmental institutions. This perhaps reflects a traditional conception of legitimacy, which is associated with legality and state sovereignty. On the confidence measure, however, a multi-stakeholder partnership like REN21 fared better. This

\footnotetext{
${ }^{66}$ Bäckstrand et al., 'The legitimacy and accountability in polycentric climate governance'; Nasiritousi and Verhaegen, 'Disentangling legitimacy'.

${ }^{67}$ Dellmuth and Tallberg, 'The social legitimacy of international organizations'.

${ }^{68}$ See also Nasiritousi and Verhaegen, 'Disentangling legitimacy'.

${ }^{69}$ Tallberg, 'The legitimacy of old and new modes of global governance'.
} 
may reflect their capabilities as an expert-based flexible institution in delivering important governance functions in the renewable energy realm. ${ }^{70}$

These results thus generate hypotheses about sources of legitimacy, differences in perceptions of legitimacy between stakeholder groups, and new versus old institutions that can be explored in further research. One factor that might affect legitimacy perceptions towards an institution is whether or not one is a citizen of one of its member states. As IRENA and UNFCCC have been rated highly and have a near universal membership, and as the IEA has been rated lower by respondents from groups of countries with few IEA members than by respondents from groups with many members, this appears probable. This could however very well be the result of other factors. In order to test this, a larger sample of respondents would be needed.

Another factor that may affect legitimacy perceptions towards an institution is how well known the institution is. The institutions that were cited as the most legitimate by respondents (IRENA, IEA, and the UNFCCC), are all fairly well known in comparison with some institutions in the sample such as the CEM. On the other hand, institutions that are even more widely known, such as the G20 and the EU, were less frequently mentioned. This indicates that respondents answer not based on how well known institutions are, but can be considered to generally understand the questions posed. While the G20 and the EU do address renewable energy, they do not have the promotion of renewable energy as primary tasks as they are general purpose institutions; but neither do the IEA and the UNFCCC that are frequently mentioned by respondents. However, the IEA and UNFCCC are at least focused on the closely related issue-areas of energy and climate change respectively. Thus, it appears that both being well known and being focused on renewable energy, or at least a closely related issue-area, are prerequisites but not sufficient conditions for being widely considered legitimate in the global renewable energy field.

Interestingly, the CEM fared poorly on all three measures of effectiveness, legitimacy, and confidence - despite involving the major energy countries. This may be because it is a relatively unknown institution, even to stakeholders in the climate and energy governance realm. ${ }^{71}$ Thus the study's results are in line with the idea that older institutions enjoy greater legitimacy, ${ }^{72}$ but as the case of IRENA shows, new institutions can also gain in legitimacy rapidly.

This points to new research avenues in terms of understanding how new institutions gain legitimacy. Arguably, IRENA's success stems from it filling a clear niche with its exclusive focus on renewable energy. This is supported by the fact that its global mandate and focus on all renewables was frequently provided as a reason by respondents for answering IRENA. In addition, IRENA has established broad cooperation with other actors and has actively promoted its work at other venues, such as during UNFCCC meetings. ${ }^{73}$ However, further research is needed to understand why the CEM, which was established around the same time, has not achieved a similar level of legitimacy.

On a general level the study has shown that a widely held perception of high legitimacy among stakeholders for institutions in the renewable energy field appears to foremost be a result of having many states as members and having expertise in energy questions. IRENA as the most frequently mentioned institution has both of these qualities. IEA has fewer members and also focuses on other types of energy sources that are non-renewable. Nevertheless, a considerable part of the legitimacy of the IEA seems to be due to its expertise. The UNFCCC has the most members out of these institutions but does not have as its core mission to focus on renewable energy and therefore cannot compete on expertise in energy questions compared to IRENA or IEA. What the results point to is that these institutions operating in a fragmented governance

\footnotetext{
${ }^{70}$ Sanderink and Nasiritousi, 'How institutional interactions can strengthen effectiveness'.

${ }^{71}$ Nasiritousi and Verhaegen, 'Disentangling legitimacy'.

${ }^{72}$ Lenz and Viola, 'Legitimacy and institutional change in international organisations'.

${ }^{73}$ Sanderink and Nasiritousi, 'How institutional interactions can strengthen effectiveness'.
} 
landscape fill various roles and have different comparative advantages. While IRENA is considered the most legitimate institution in the renewable energy field, it is possible that the IEA would be considered most legitimate in the broader energy field and the UNFCCC in the climate change field. Because of increasing institutional complexity, institutions' legitimacy is thus likely to be dependent on keeping themselves relevant for, and conforming to the normative expectations of, a number of stakeholder groups. ${ }^{74}$ Taken together, this highlights the importance of outreach activities by institutions, in order not only to inform stakeholders about their ongoing work, but also to solicit input from key stakeholders.

While this study has sought to map legitimacy perceptions among stakeholders in climate and energy governance, a number of limitations of the study should be highlighted to guide future research. First, the wording of the questions could have led the respondents to think in terms of purpose as the question asked about institutions that promote renewable energy. Perhaps different open questions that asked about institutions in the global renewable energy field without mentioning promotion of renewable energy would yield other answers. On the other hand, international institutions are often created with the aim to address specific problems, ${ }^{75}$ so it is reasonable to believe that respondents would have thought about renewable energy promotion if asked to evaluate institutions in the renewable energy field. Second, it is possible that the sources of legitimacy vary depending on the institutions most frequently mentioned. It could also be that different institutions have different requirements for purpose, procedure, and performance as judged by various audiences. ${ }^{76}$ While our results are in line with previous research, ${ }^{77}$ further research into other issue-areas would be required to understand whether our findings are generalisable.

Finally, the results presented here have been descriptive. More extensive research efforts would be needed to gain larger samples to be able to perform statistical analyses of the data. Such studies could ask respondents to rank institutions in order to explore their relative legitimacy. While this study shows which institutions enjoy a widely held perception of high legitimacy among stakeholders, it does not say much about the legitimacy of the less mentioned institutions. Combining open and closed questions in a survey may address this issue. Future studies could also further examine the relationship between legitimacy of individual institutions and the overall governance field, how patterns of cooperation and competition affect legitimacy, as well as why stakeholders hold the perceptions that they do. While this article presented survey data, other complementary methods would likely be needed to not only map stakeholder perceptions of legitimacy, but to also start understanding how they are formed. Through this article we hope to inspire such research also in other fields of global governance.

Acknowledgements. The authors would like to thank Karin Bäckstrand and Lisa Sanderink for carrying out the survey with us. An early version of this article was presented in the panel 'Governance Of The Climate-Energy Nexus: Institutional Complexity, Effectiveness, and Legitimacy' at the ISA Annual Convention in Toronto in 2019 and at a LegGov workshop in Toronto in 2019. We are thankful for constructive comments received from participants, and particularly from Matthew Hoffmann who was discussant at the ISA panel. Moreover, we would like to thank Jonas Tallberg and Soetkin Verhaegen for valuable inputs on an earlier draft and three anonymous reviewers for very thorough and constructive comments. The authors would like to acknowledge support from the Swedish Energy Agency (CLIMENGO project, 'Mapping the Institutional Complexity of Global Climate and Energy Governance, Evaluating its Effectiveness and Legitimacy, and Developing a Knowledge Base for Decision-Makers', contract number 40657-1).

\footnotetext{
${ }^{74}$ Jonathan Symons, 'The legitimation of international organisations: Examining the identity of the communities that grant legitimacy', Review of International Studies, 37:5 (2011), pp. 2557-83.

${ }^{75}$ Binder and Heupel, 'The legitimacy of the UN Security Council'.

${ }^{76}$ Bernstein, 'Legitimacy in intergovernmental and non-state global governance'.

${ }^{77}$ Dellmuth and Tallberg, 'The social legitimacy of international organizations', Tallberg, 'The legitimacy of old and new modes of global governance'.
} 
Naghmeh Nasiritousi is a postdoctoral research fellow at Stockholm University. Her research focuses on international climate change politics, energy governance, and issues of legitimacy and effectiveness. Her research has been published in journals such as Nature Climate Change; European Journal of International Relations; International Studies Quarterly; Global Environmental Politics; International Environmental Agreements: Politics, Law and Economics; and Annual Review of Political Science.

Hugo Faber is a PhD student in Political Science at Södertörn University. He has previously worked as a research assistant at Stockholm University and as an analyst at the Swedish Climate Policy Council and at the Swedish Agency for Public Management. His research focuses on power, politics, and elite discourse in relation to the energy transition and the phasing out of fossil fuels.

Cite this article: Nasiritousi, N., Faber, H. 2021. Legitimacy under institutional complexity: Mapping stakeholder perceptions of legitimate institutions and their sources of legitimacy in global renewable energy governance. Review of International Studies 47, 377-398. https://doi.org/10.1017/S0260210520000431 